\title{
Floral structure in the neotropical palm genus Chamaedorea (Arecoideae, Arecaceae)
}

\author{
by \\ Aino Askgaard ${ }^{1}$, Fred W. Stauffer ${ }^{1}$, Donald R. Hodel ${ }^{2}$, Anders S. Barfod ${ }^{3}$ \\ ${ }^{1}$ Conservatoire et Jardin botaniques, Ch. de l'Impératrice 1, CP 60, CH-1292 Chambésy, Genève, Switzerland \\ aino.casper@bluewin.ch, fred.stauffer@ville-ge.ch \\ ${ }^{2}$ University of California, 4800 E. César E. Chávez Avenue, Los Angeles, CA 90022, USA. drhodel@ucdavis.edu \\ ${ }^{3}$ Department of Biological Sciences, University of Aarhus, Ny Munkegade bygn. 1540, DK-8000 Århus C., Denmark \\ anders.barfod@biology.au.dk (corresponding author)
}

\begin{abstract}
Askgaard, A., Stauffer, F.W., Hodel, D.R. \&. Barfod, A.S. 2008. Floral structure in the neotropical palm genus Chamaedorea (Arecoideae, Arecaceae). Anales Jard. Bot. Madrid 65(2): 197210.

Male and female floral structure has been studied in 28 species of Chamaedorea, the largest palm genus present in the Neotropics. The taxa investigated represent all subgenera according to the most recent taxonomic revision of the group. Morphological, histological and cytological features that are known to be of importance for interactions with visiting insects were studied and their putative role in protecting the flowering parts assessed. The taxonomic distribution of selected characters is in some cases congruent with relationships inferred by recently published molecular studies within the group.
\end{abstract}

Keywords: Arecaceae, Chamaedoreeae, Chamaedorea, floral structure, anatomy, floral defenses, infrageneric classification.

\section{Introduction}

The genus Chamaedorea Willd. is the largest palm genus in the Neotropics and forms, together with Gaussia H. Wendl., Hyophorbe Gaertn., Synencanthus $\mathrm{H}$. Wendl. and Wendlandiella Dammer the tribe Chamaedoreeae Drude (Dransfield \& al., 2005). Thomas \& al. (2006) explored the relationships within the genus based on the low-copy nuclear genes PRK and RPB2, whereas Cuenca \& Asmussen-Lange (2007) published a molecular study of the tribe, based on plastid DNA sequences. Both studies show that

\section{Resumen}

Askgaard, A., Stauffer, F.W., Hodel, D.R. \&. Barfod, A.S. 2008. Estructura floral de la palma neotropical del género Chamaedorea (Arecoideae, Arecaceae). Anales Jard. Bot. Madrid 65(2): 197-210 (en inglés).

Se ha estudiado la estructura de las flores masculinas y femeninas en 28 especies de Chamaedorea, el género de palmas con mayor número de especies en la región neotropical. Los táxones investigados representan a todos los subgéneros contemplados en la más reciente revisión taxonómica del grupo. Se han estudiado los caracteres morfológicos, histológicos y citológicos de mayor importancia en cuanto a la visita de insectos y se ha examinado su rol dentro de la protección de los órganos florales. La distribución taxonómica de caracteres seleccionados ha demostrado, en algunos casos, ser congruente con las relaciones inferidas por los más recientes estudios moleculares que incluyen al grupo.

Palabras clave: Arecaceae, Chamaedoreeae, Chamaedorea, estructura floral, anatomía, defensas florales, clasificación infragenérica

Chamaedorea is a strongly supported monophyletic group, which is in agreement with classifications based on morphological characters such as Uhl \& Dransfield (1987), and Dransfield \& Uhl (1998). However, in both cases the molecular evidence presented is too inconclusive to derive a classification of the genus.

Estimates of the number of species in Chamaedorea range from 77 (Henderson \& al., 1995) to more than 105 species (Hodel 1992a; 1992b; 1995; Hodel \& al., 1995). Taxonomic delimitation within the genus has been rendered difficult by a combination of complex 
vegetative and reproductive morphological characters, insufficient data and extensive sympatry (Uhl \& Dransfield, 1987; Henderson \& al., 1995; Hodel, 1999; Bacon \& Bailey, 2006). The genus is distributed from Mexico in the north to Bolivia in the south with the centre of diversity situated in Meso-America. Within this strictly dioecious genus, most species are small to medium-sized, solitary, and grow in the understorey of lowland and mountain forests. Chamaedorea fractiflecta Hodel \& Castillo occurs up to $2900 \mathrm{~m}$ altitude in Mexico and Guatemala, which is the record within the genus (Hodel, 1992a).

Due to their moderate size, ease of cultivation and attractive foliage many species have been introduced into cultivation. Chamaedorea leaves have been extracted from Meso-American forests for years and exported for use in flower arrangements. "Xate" is the collective term for the species of Chamaedorea that are used in the ornamental cut leaf trade. Three species are particularly important $C$. elegans Mart., C. oblongata Mart. and C. ernesti-augustii H. Wendl. From the latter species alone 227 million leaves were collected in the areas of Petén and Chiquibul (Guatemala) in 2001 , which constitutes $67 \%$ of the total Xate extraction (Ramírez, 2002).

Studies of the reproductive biology of palms have revealed a wide range of adaptations in the flower structure that match the behavioral characteristics of their visitors. Palm flowers are generally protected against the deleterious effects of the visiting fauna by a number of structural and histochemical features such as fibres and sclerenchyma, raphide-containing idioblasts and tannin-rich tissues (Uhl \& Moore, 1973). The most common pollen dispersing agents in palms are beetles, followed by bees and flies (Henderson, 2002). The reproductive ecology of only a few species of Chamaedorea has been studied in detail and consequently, little is known on the evolutionary drivers behind the diversity in flower structure found within the genus. The following species have been recorded to be insect pollinated: Chamaedorea costaricana Oerst. (Henderson, 1986), C. tepejilote Liebm. (as C. wendlandiana [Oerst.] Hemsl.) (Croat, 1978), C. ernesti-augustii (Hodel, 1992a), C. tepejilote Liebm., C. oblongata Mart, and C. neurochlamys Burret (Morgan, pers. comm.). Listabarth (1992) has demonstrated that transfer of pollen grains in Chamaedorea pinnatifrons (Jacq.) Oerst. is mediated by a mechanism called insect-induced wind pollination. The male flowers open by lateral slits and the activity of numerous thrips and beetles creates puffs of the powdery pollen in the air. These are carried by air currents to the female plants, which are rarely visited by insects. Wind pollination was recorded in C. tepejilote Liebm. (Bawa \& al., 1985b [as C. exorrbiza
H. Wendl. ex Guillaum.], Barry, 1957), C. alternans H.A. Wendl. (Otero-Arnaiz \& Oyama, 2001, Fisher \& Moore, 1977), C. radicalis Mart. (Berry \& Gorchov, 2004), C. oblongata Mart., C. pochutlensis Liebm., and C. seifrizii Burret (Hodel, 1992a).

Apart from a study by Uhl and Moore (1971) including four species of the subgenus Eleutheropetalum, few efforts have been made to describe Chamaedorea flowers in detail. Here we will investigate the variation in flower structure of 28 Chamaedorea species, which represents all the subgenera according to Hodel (1992a). We will focus on morphological, histological and cytological features that are known to be of importance for interactions with visiting insects whether these are beneficial (e.g. pollinators) or harmful (e.g. herbivores) for the plant.

\section{Material and methods}

The present study is mainly based on twenty eight species, representing all six subgenera currently accepted for the genus (see Table 1). Most species were cultivated by Donald Hodel in the Virginia Robinson Garden, Los Angeles (USA) and are vouchered at the Bailey Hortorium (BH). A few additional species were sampled by the first author in Costa Rica (unvouchered) and by Finn Ervik in Ecuador (Ervik 39 and 81). From each species 1-3 normally developing flowers in late bud or anthesis were fixed in $70 \%$ ethanol and infiltrated and embedded in Kulzer's Technovit 7100 (2-hydroxyethyl methacrylate [HEMA]). Entire flowers were sectioned at 6-12 microns using a Reichert ${ }^{\mathrm{TM}}$ rotary microtone and stained with Toluidine Blue and embedded in Euparal ${ }^{\mathrm{TM}}$. Sections were photographed with a Leitz Orthoplan microscope and Orthomat photo-equipment. Measurements pertaining to the floral structure were all made from the resulting micrographs. Materials for study in the scanning electronic microscope (Jeol JSM-840 $0^{\mathrm{TM}}$ ) were prepared in a Thermo Electrical Critical Point Dryer BIO RAD CDP750 $0^{\mathrm{TM}}$ and sputter-coated with gold. A complete set of fixed samples is deposited in the Department of Biology of the University of Aarhus, Denmark, and the permanent anatomical slides are deposited in the Laboratory of Micro-Morphology of the Conservatory and Botanical Garden of Geneva, Switzerland. Throughout the paper the classification of Hodel (1992a) is followed.

\section{Results}

\section{The inflorescence and the flowers}

The strictly unisexual inflorescences of Chamaedorea are either presented among the leaves (e.g. C. 
Table 1. The Chamaedorea species included in this study and their distribution. Subgenus according to Hodel (1992a) is indicated in brackets after the species name. In parentheses are indicated the accession nos. of the sampled male and female plants respectively. These nos. refer to the Don Hodel palm collection in Los Angeles, which is vouchered at the Bailey Hortorium, Cornell University, New York $(\mathrm{BH})$. 'Bis' indicates where it is the F1 progeny of an accession that has been sampled; $m$, male flowers; $f$, female flowers.

\begin{tabular}{|c|c|c|}
\hline Taxa & Sex (accession no.) & Distribution \\
\hline C. allenii L.H. Bailey [Stephanostachys] & m (Hodel 742-bis), f (Hodel 724-bis) & Panama, Colombia \\
\hline C. alternans H.A. Wendl. [Stephanostachys] & m (Hodel s.n.), f (Hodel 751) & Mexico \\
\hline $\begin{array}{l}\text { C. brachyclada H.A. Wendl. } \\
\text { [Chamaedoropsis] }\end{array}$ & m (Hodel 705A-bis), f (Hodel 705B-bis) & $\begin{array}{l}\text { Costa Rica, } \\
\text { Panama }\end{array}$ \\
\hline $\begin{array}{l}\text { C. brachypoda Standl. \& Steyerm. } \\
\text { [Chamaedoropsis] }\end{array}$ & m (Hodel 861), f(Hodel 827) & $\begin{array}{l}\text { Guatemala, } \\
\text { Honduras }\end{array}$ \\
\hline C. castillo-montii Hodel [Chamaedoropsis] & m (Hodel 868A-bis), $f$ (Hodel 868B-bis) & Guatemala \\
\hline C. cataractarum Mart. [Stephanostachys] & m (Hodel 786 A), f (Hodel 786 B) & Mexico \\
\hline $\begin{array}{l}\text { C. deckeriana (Klotzsch) Hemsl. } \\
\text { [Stephanostachys] }\end{array}$ & m (Askgaard s.n.) , f (Hodel 780) & $\begin{array}{l}\text { Costa Rica, } \\
\text { Panama }\end{array}$ \\
\hline C. elegans Mart. [Collinia] & m (Hodel 686), f (Hodel 767) & Mexico, Guatemala, Belize \\
\hline $\begin{array}{l}\text { C. ernesti-augustii H.A. Wendl. } \\
\text { [Eleutheropetalum] }\end{array}$ & m (Askgaard s.n. ), f (Hodel 755 B) & $\begin{array}{l}\text { Mexico, Guatemala, Belize, } \\
\text { Costa Rica, Honduras }\end{array}$ \\
\hline $\begin{array}{l}\text { C. fragrans (Ruiz \& Pav.) Mart. } \\
\text { [Chamaedoropsis] }\end{array}$ & m (Hodel 818), f (Hodel 822) & Peru \\
\hline $\begin{array}{l}\text { C. geonomiformis H.A. Wendl. } \\
\text { [Chamaedorea] }\end{array}$ & m (Hodel 792 A), f (Hodel 792 B) & $\begin{array}{l}\text { Mexico, Guatemala, Belize, } \\
\text { Honduras, Colombia }\end{array}$ \\
\hline $\begin{array}{l}\text { C. guntheriana Hodel \& Uhl } \\
\text { [Chamaedoropsis] }\end{array}$ & m (Hodel 746A), f (Hodel 746B) & Panama \\
\hline C. hopperiana Hodel [Chamaedorea] & m (Hodel 772-bis), f (Hodel 804-bis) & Mexico \\
\hline C. klotzschiana H.A. Wendl. [Chamaedorea] & m (Hodel 862 A), f (Hodel 802 B) & Mexico \\
\hline $\begin{array}{l}\text { C. linearis (Ruiz \& Pav.) Mart. } \\
\text { [Morenia] }\end{array}$ & m (Ervik 39), f (Ervik 81) & $\begin{array}{c}\text { Ecuador, Venezuela, Colombia, } \\
\text { Peru, Bolivia }\end{array}$ \\
\hline $\begin{array}{l}\text { C. metallica O.F. Cook ex H.E. Moore } \\
\text { [Eleutheropetalum] }\end{array}$ & m (Hodel 799A), f (Hodel 799B) & Mexico \\
\hline C. microspadix Burret [Moreniella] & m (Hodel 759 A), f (Sullivan s.n.) & Mexico \\
\hline C. oreophila Mart. [Stephanostachys] & m (Hodel 765A), f (Hodel 765B) & Mexico \\
\hline $\begin{array}{l}\text { C. pinnatifrons (Jacq.) Oerst. } \\
\text { [Chamaedorea] }\end{array}$ & m (Askgaard s.n.), f (Hodel 707) & $\begin{array}{c}\text { Mexico, Guatemala, El Salvador, } \\
\text { Honduras, Nicaragua, Costa Rica, } \\
\text { Panama, Venezuela, Colombia, } \\
\text { Peru, Brazil, Ecuador, Bolivia }\end{array}$ \\
\hline C. pochutlensis Liebm. [Chamaedoropsis] & m (Hodel 753), f (Tallman s.n.) & Mexico \\
\hline $\begin{array}{l}\text { C. quezalteca Standl. \& Steyerm. } \\
\text { [Chamaedoropsis] }\end{array}$ & m (Hodel 800), f (Hodel 783) & $\begin{array}{l}\text { Mexico, Guatemala, } \\
\text { El Salvador, Honduras }\end{array}$ \\
\hline C. radicalis Mart. [Moreniella] & m (Hodel 793), f (Hodel 809) & Mexico \\
\hline C. sartorii Liebm. [Eleutheropetalum] & m (Hodel 756A), f (Hodel 756B) & Mexico, Honduras \\
\hline C. seifrizii Burret [Chamaedoropsis] & m (Sullivan s.n.), f (Hodel s.n.) & Mexico, Belize, Guatemala, Honduras \\
\hline $\begin{array}{l}\text { C. stenocarpa Standl. \& Steyerm. } \\
\text { [Chamaedoropsis] }\end{array}$ & m (Hodel 824A), $\mathrm{f}$ (Hodel 824B) & $\begin{array}{l}\text { Guatemala, Costa Rica, } \\
\text { Panama }\end{array}$ \\
\hline $\begin{array}{l}\text { C. stolonifera H.A. Wendl. } \\
\text { [Eleutheropetalum] }\end{array}$ & m (Hodel 771), f (Hodel 757) & Mexico \\
\hline C. tenella H.A. Wendl. [Chamaedorea] & m (Hodel 714-bis), f (Hodel 714-bis) & Mexico, Costa Rica \\
\hline $\begin{array}{l}\text { C. tuerckheimii (Dammer) Burret } \\
\text { [Chamaedoropsis] }\end{array}$ & m (Hooper s.n.), f (Hodel 750) & $\begin{array}{l}\text { Mexico, } \\
\text { Guatemala }\end{array}$ \\
\hline
\end{tabular}


oreophila Mart. and C. geonomiformis H. Wendl.) or below the leaves (e.g. C. oblongata Mart. and C. fragrans Mart.). Usually a single inflorescence is borne at each node but in some species several inflorescences are produced such as in the subgenera Morenia (Ruiz \& Pavon) Hodel and Stephanostachys Klotzsch. The inflorescences are usually branched to one to two orders. Less often they are spicate or furcate such as in C. allenii L.H. Bailey and C. deckeriana (Klotzsch) Hemsl. The staminate inflorescence is often branched to a higher order than the pistillate homologue and in many species such as C. metallica O.F. Cook and $C$. ernesti-augustii $\mathrm{H}$. Wendl. branching is a variable feature ranging from spicate to bearing several branches. The prophyll and two or more peduncular bracts are tubular, coriaceous to chartaceous. During development and anthesis, the rachis and the rachillae are green, usually turning red or orange at fruit maturation.

The flowers are spirally arranged on the rachillae. They are usually solitary (Figs. 1,2) but in the subgenera Moreniella Hodel and Morenia (Fig. 1 C, D) the staminate flowers are arranged in sympodial pairs or short cincinni. The flowers are sessile and often more or less sunken in pits, particularly in species with fleshy rachillae. They vary from being densely (Figs. 1 B, 2 B) to remotely arranged (Figs. 1 A, 2 A). Flowers are often more densely aggregated on staminate plants as compared to the pistillate plants of the same species. The flowers are trimerous, symmetrical and normally not exceeding $4-5 \mathrm{~mm}$ across. The calyx is composed of 3 basally united, free and distally imbricate sepals. The sepals are greenish or pale and are always shorter than the petals. Tannin-containing cells are absent from all parts of the flowers. For additional information see Table 2, which includes morphological and anatomical characters diagnostic for each species.

\section{The staminate flowers (Figs. 3 A-C, G, 4 A-C)}

The size of the staminate flowers ranges between 2 $\times 2.3 \mathrm{~mm}$ (C. guntheriana Hodel \& N. W. Uhl) and 4.7 $\times 3.5 \mathrm{~mm}$ (C. geonomiformis H. Wendl.). Sepals are between 0.3 and $1.7 \mathrm{~mm}$ long. The corolla has three usually valvate and free petals (Fig. $3 \mathrm{~A}$ ), but in some species the distal parts of the petals are connate and fused to the pistillode (Fig. 3 B) so that flowers can only be accessed through longitudinal slits between the petals (C. geonomiformis, C. hooperiana Hodel, $C$. klotzschiana $\mathrm{H}$. Wendl., C. pinnatifrons and C. tenella $\mathrm{H}$. Wendl.). The petals are usually acute and rarely thickened in C. bracbyclada H. Wendl., C. deckeriana, C. metallica, C. oreophila, and C. sartorii. They vary in length from 1.5 and $4.4 \mathrm{~mm}$ and are normally longer than the pistillode. Mostly the petals are yellow but they also be orange in (C. ernesti-augustii, C. fragrans, C. metallica, C. sartorii, C. stolonifera $\mathrm{H}$. Wendl.), white (C. castillo-montii Hodel, C. linearis, C. microspadix Burret, C. tuerckheimii (Dammer) Burret) or green (C. brachyclada, C. deckeriana, C. stenocarpa Standl. \& Steyerm.). The androecium is typically composed of six stamens, which are more or less inserted at the same level (Fig. 4 B). The stamens vary between 0.6 and $2.1 \mathrm{~mm}$ in length and they are usually shorter than the petals, except in C. deckeriana. The filaments range between 0.2 and $1.6 \mathrm{~mm}$ in length and thick. The anthers are dorsifixed and introrse. The conspicuous pistillode consists of three sterile, equally developed carpels that are completely to partially fused (Fig. 4 B). The pistillodes are between 0.9 and $3.6 \mathrm{~mm}$ long and often columnar (Figs. $3 \mathrm{~B}, 4 \mathrm{~A}$ ). None of the pistillodes dissected contained locules or ovules. The pistillode is often equal to or exceeds the androecium in length. It was only noticeably shorter in C. alternans, C. bracbyclada, C. cataractarum Mart., C. deckeriana and C. linearis. Septal nectaries were not detected in any of the species. In C. radicalis and $C$. stolonifera we observed putative secretory cells in the ventral flanks of the sterile carpels. The abaxial mesophyll layers of the petals of Chamaedorea ernestiaugustii, C. fragrans, C. guntheriana, C. hooperiana, C. linearis, C. metallica, C. oreophila, C. quetzalteca Mart., C. sartorii, and C. stolonifera differ by being composed of small-sized, densely staining cells (Fig. 4 D). Both the filaments and the sterile carpels are supplied by a single vascular bundle. Raphide containing idioblasts are visible in perianth and pistillode. They are densely aggregated in the anthers (Figs. 3 G, 4 C), but almost lacking in the filaments. Sclerenchymatic cells are sometimes present in the abaxial layers of sepals and petals. In almost half of the species investigated hat-shaped stegmata (Fig. 4 I) were observed in the petals. Table 3 gives an overview of anatomical features such as raphide idioblasts, sclerenchyma and stegmata that may play a role in floral protection. The different species are ranked according to putative, decreasing degree of protection.

\section{The pistillate flowers (Figs. 3 D-F, 4 E-I)}

The pistillate flowers range in size between $1.5 \times$ $2.5 \mathrm{~mm}$ (C. tenella) and $4.8 \times 4 \mathrm{~mm}$ (C. ernesti-augustii). The sepals are between 0.5 and $2.5 \mathrm{~mm}$ long. The corolla is composed of three petals between 1.1 and $4.8 \mathrm{~mm}$ long, which in most species are imbricate and free (Fig. 3 D). Exceptions to this are Chamaedorea elegans (Fig. 3 F), C. ernesti-augustii, C. linearis, C. metallica (Fig. 3 E), C. sartorii, and C. stolonifera, all with valvate petals. The petals are generally acute 


\begin{tabular}{|c|c|c|c|c|c|c|c|c|c|c|c|c|c|c|c|c|c|c|c|c|c|c|c|c|c|c|c|}
\hline C. tuerckheimii & & & & $\times$ & & & & & & & & & & $\times$ & $\times$ & & & & & & & & & & & & \\
\hline C. tenella & & & $\times$ & $\times$ & $\times$ & & & $\times$ & & & & & & & & & & & $\times$ & & & & & & & & \\
\hline C. stolonifera & & & & & & & $\times$ & & & $x$ & $\times$ & & & & & $\times$ & $\times$ & & $x$ & $\times$ & $\times$ & & & & & & \\
\hline C. stenocarpa & & & & $\times$ & & & & & & & & $\times$ & & & & & & & & & & & & & & & \\
\hline C. seifrizii & & & & & & & & & & & & & & & & & & & $\times$ & & & & & & $\times$ & $\times$ & $\times$ \\
\hline C. sartorii & & & & & & & $\times$ & & $\times$ & $\times$ & $\times$ & & & & & $\times$ & $\times$ & & $\times$ & $\times$ & & & & $\times$ & & $\times$ & $\times$ \\
\hline C. radicalis & & & & $\times$ & $\times$ & & & & & & & & $\times$ & & & & & & & & & & $\times$ & $\times$ & 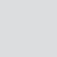 & $\times$ & \\
\hline C. quezalteca & & & & & $\widehat{x}$ & & & & & & & & & & & $\times$ & & & $\times$ & & & & & & & & \\
\hline C. pochutlensis & & & & & & & & & & & & & & & & & & & $\times$ & & & & & & $\times$ & 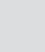 & $x$ \\
\hline C. pinnatifrons & & & & & & & & $\times$ & & & & & & & & & & & & & & & & & $\times$ & $\times$ & $\times$ \\
\hline C. oreophila & $\times$ & & $\times$ & $\times$ & $\times$ & & & & $\times$ & & & & & & & $\times$ & & & & & $\times$ & & & & & & \\
\hline C. microspadix & & & & & $\times$ & & & & & & & & & $\times$ & $\times$ & & & & & & & & & & & & $\times$ \\
\hline C. metalica & & & & $\widehat{x}$ & & & $\times$ & & $\times$ & $x$ & $\times$ & & & & & $\times$ & $\times$ & & $\times$ & $\times$ & & & & & & & \\
\hline C. linearis & $\times$ & & & & $\times$ & & $\times$ & & & & & & & $\times$ & $\times$ & $\times$ & & & & & & $\times$ & & & & & \\
\hline C. klotzschiana & & & & & & & & $x$ & & & & & & & & & & & & & & & & & $\times$ & & $\times$ \\
\hline C. hooperiana & & & & & & & & $\times$ & & & & & & & & $\times$ & & & $\times$ & & & & & & $x$ & . & $\times$ \\
\hline C. guntheriana & & & & $\times$ & & & & & & & & & & & & $\times$ & & & & & & & & & & & \\
\hline C. geonomiformis & & & & & $\times$ & & & $\times$ & & & & & & & & & & & & & & & & & & & $\times$ \\
\hline C. fragrans & & & & & & & & & & $\times$ & $\times$ & & & & & $\times$ & $\times$ & & $\times$ & & & & & & $\times$ & & \\
\hline C. ernestiaugustii & & & & $\widehat{x}$ & & & $\times$ & & & $x$ & $\times$ & & & & & $\times$ & $x$ & & $\times$ & $\times$ & & & & & $\times$ & & $\times$ \\
\hline C. elegans & & & & & & & $\times$ & & & & & & & & & & & & & & & & & & $\times$ & $\times$ & $\times$ \\
\hline C. deckeriana & $\times$ & & $\times$ & $\times$ & $\times$ & $\times$ & & & $\times$ & & & $\times$ & & & & & & $\times$ & & $\times$ & & $\times$ & & & & & \\
\hline C. cataracterum & & & & & $\times$ & & & & & & & & & & & & & & $\times$ & $\times$ & $\times$ & $\times$ & & & & & \\
\hline C. castillomontii & & & $\times$ & $\times$ & $\times$ & & & & & & & & & $\times$ & $\times$ & & & & & & & & & $\times$ & & & \\
\hline C. brachypoda & & & & & & & & & & & & & & & & & & & $x$ & & $x$ & & $x$ & & & & \\
\hline C. brachyclada & & & & & & & & & $\times$ & & & $\times$ & & & & & & & & & & $\times$ & & & & & \\
\hline C. alternans & $\times$ & $\widehat{x}$ & & & $x$ & & & & & & & & & & & & & & & & $\times$ & $\times$ & & & & & \\
\hline C. allenii & & & $\times$ & $\times$ & $\times$ & $\times$ & & & & & & & & & & & & & & & & & & & & & \\
\hline & 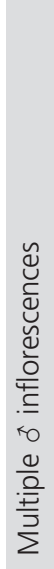 & 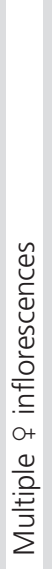 & 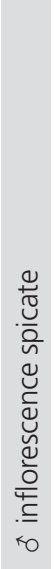 & 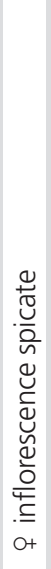 & 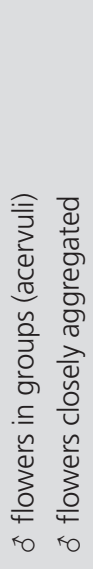 & 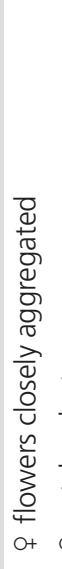 & $\begin{array}{l}0 \\
0 \\
\frac{\pi}{\pi} \\
\frac{\pi}{\pi} \\
\frac{n}{\pi} \\
\frac{\pi}{0} \\
0 \\
0+\end{array}$ & 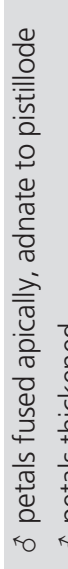 & 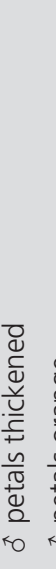 & 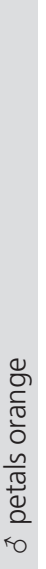 & 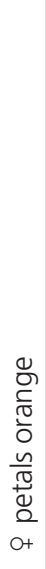 & 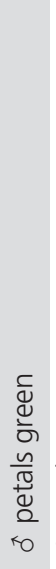 & 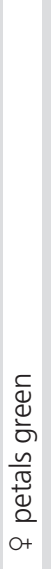 & 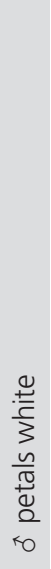 & 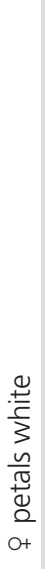 & 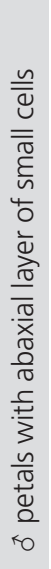 & 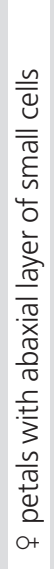 & 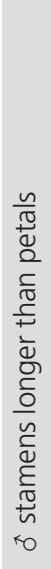 & 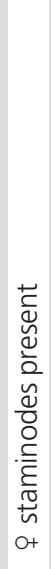 & 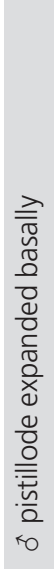 & 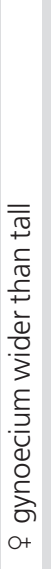 & 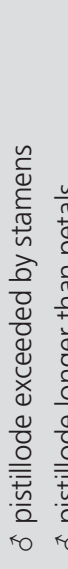 & 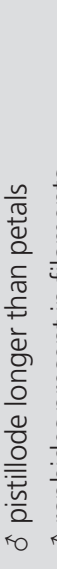 & 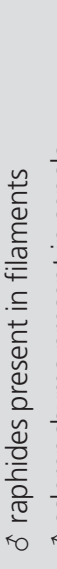 & 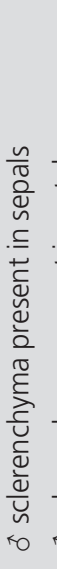 & 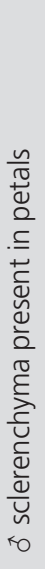 & 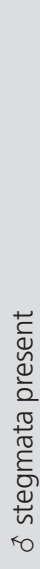 \\
\hline
\end{tabular}



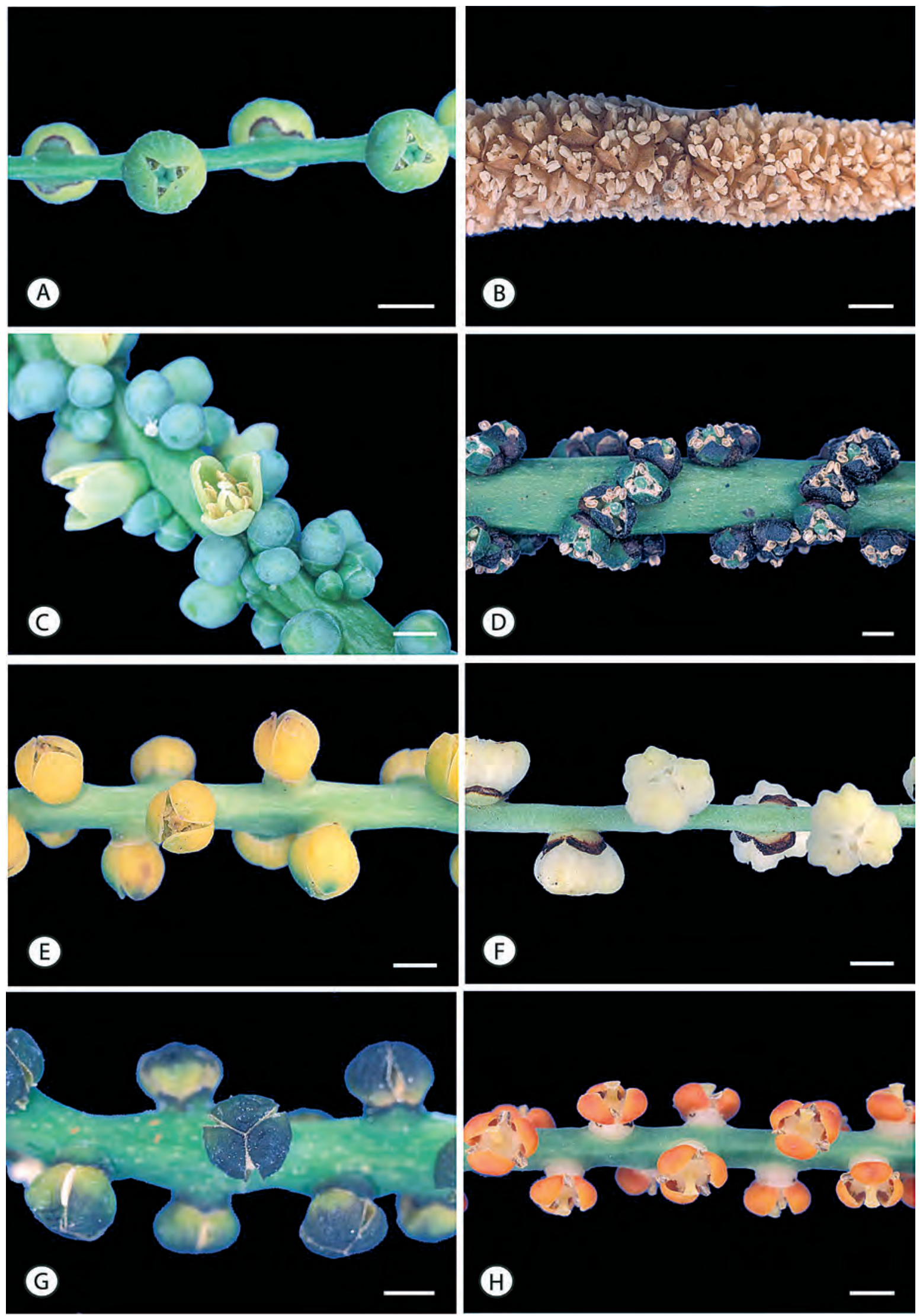

Fig. 1. Male inflorescences of Chamaedorea: A, C. elegans; B, C. oreophila; C, C. microspadix; D, C. radicalis; E, C. pochutlensis; F, C. tuerckheimii; G, C. klotzschiana; H, C. ernesti-augustii. All scale bars $=2 \mathrm{~mm}$. 

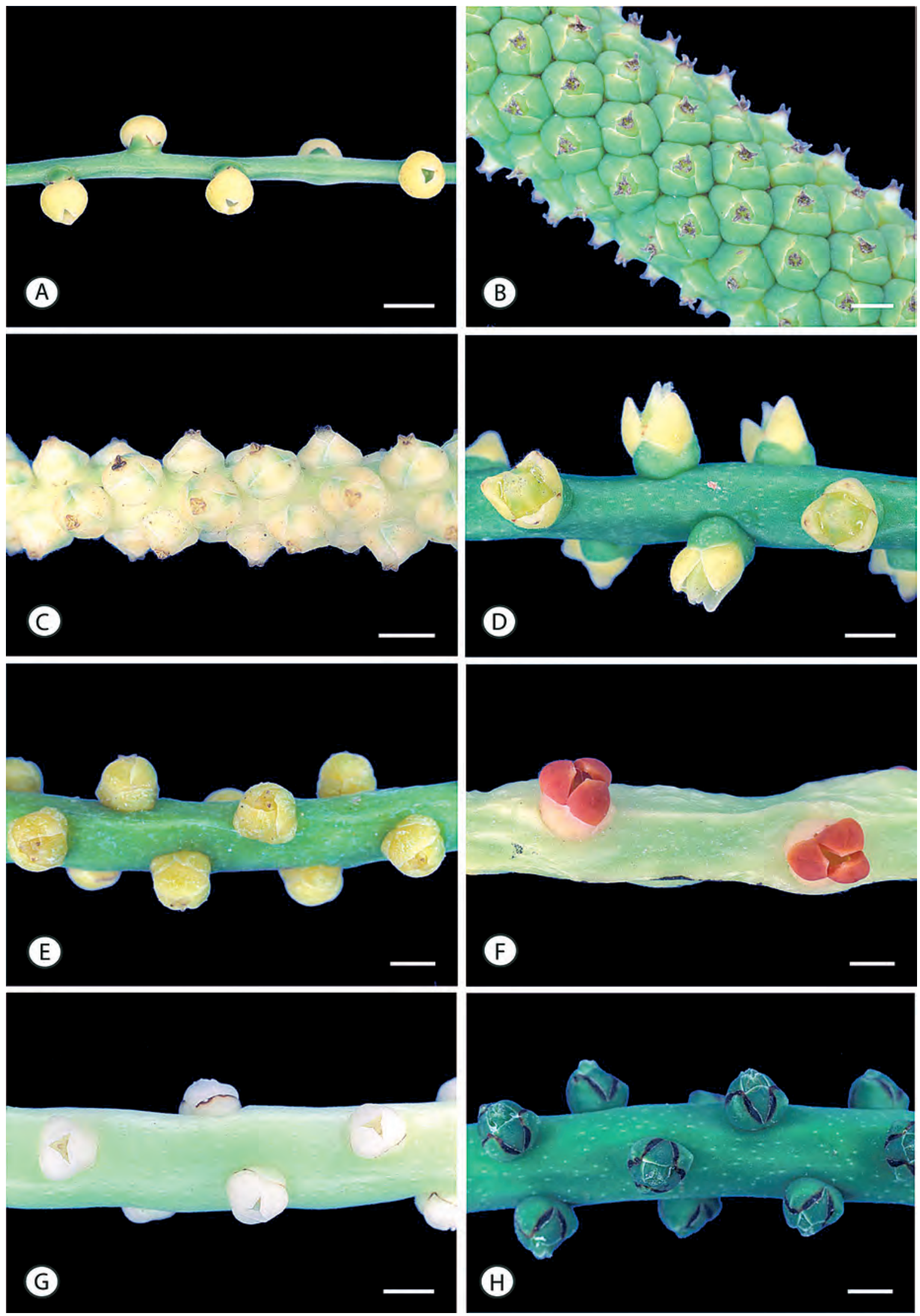

Fig. 2. Female inflorescences of Chamaedorea: A, C. elegans; B, C. deckeriana; C, C. oreophila; D, C. microspadix; E, C. pinnatifrons; F, C. sartorii; G, C. tuerckheimii; H, C. radicalis. All scale bars $=2 \mathrm{~mm}$. 

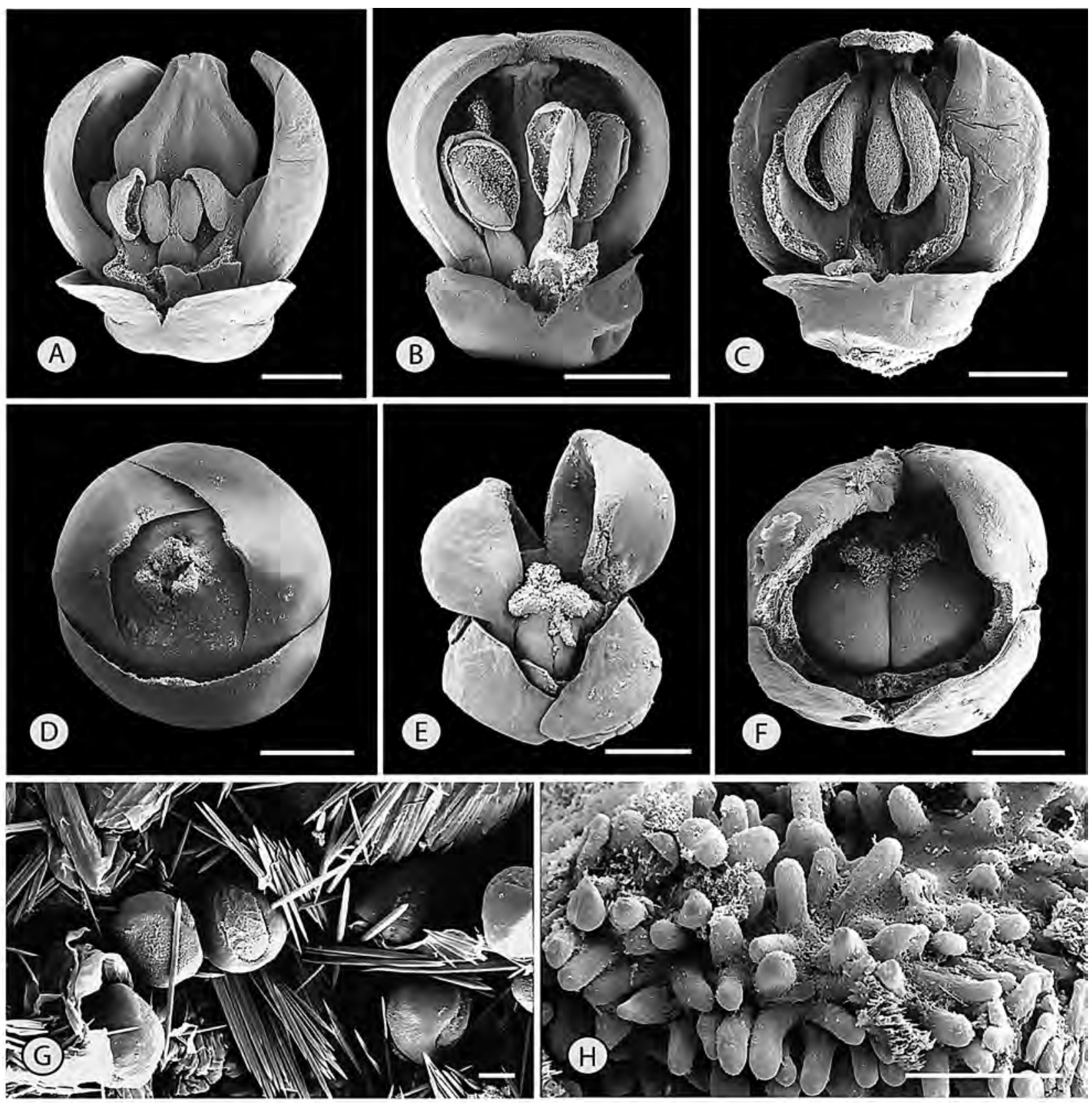

Fig. 3. Flowers of Chamaedorea: A, C. brachypoda, male flower, one petal removed, scale bar = $1 \mathrm{~mm}$. B, C. hooperiana, male flower, one petal removed, scale bar $=1 \mathrm{~mm}$. C, C. metallica, male flower, one petal removed, scale bar = $1 \mathrm{~mm}$. D, C. pochutlensis, female flower, scale bar $=1 \mathrm{~mm}$. E, C. metallica, female flower, one petal removed, scale bar $=1 \mathrm{~mm}$. F, C. elegans, female flower, one petal removed, scale bar $=1 \mathrm{~mm}$. G, C. linearis, male flower, raphide idioblasts located among the pollen in anthers, scale bar $=10$ microns. H, C. metallica, female flower, stigmatic papillae, scale bar $=100$ microns.

to rounded apically and often conspicuously thickened. The colour is frequently yellow but can also be orange in C. ernesti-augustii, C. metallica, C. sartorii, C. stolonifera, white in C. castillo-montii, C. linearis, $C$. microspadix Burret C. tuerckheimii or green in C. radicalis Mart. Staminodes are lacking or, when present, between 0.1 and $0.8 \mathrm{~mm}$ long tooth-like appendages such as in C. brachypoda, C. cataracterum, C. ernestii- augustii, C. fragrans, C. hopperiana, C. metallica, C. pochutlensis Liebm., C. quetzalteca, C. sartorii, C. seifrizii Burret, C. stolonifera and C. tenella. The large staminodes of C. brachypoda are inserted in two alternate whorls. Like in other species of Chamaedorea they do not develop thecae.

The gynoecium is tricarpellate, septate and syncarpous (Fig. 4 E). It varies in length between 1.1 and 


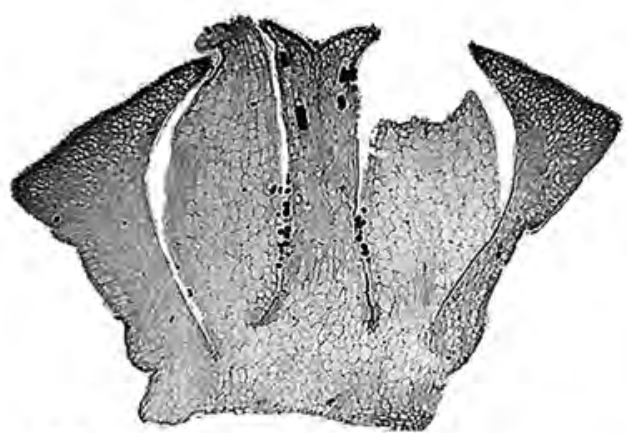

(A)
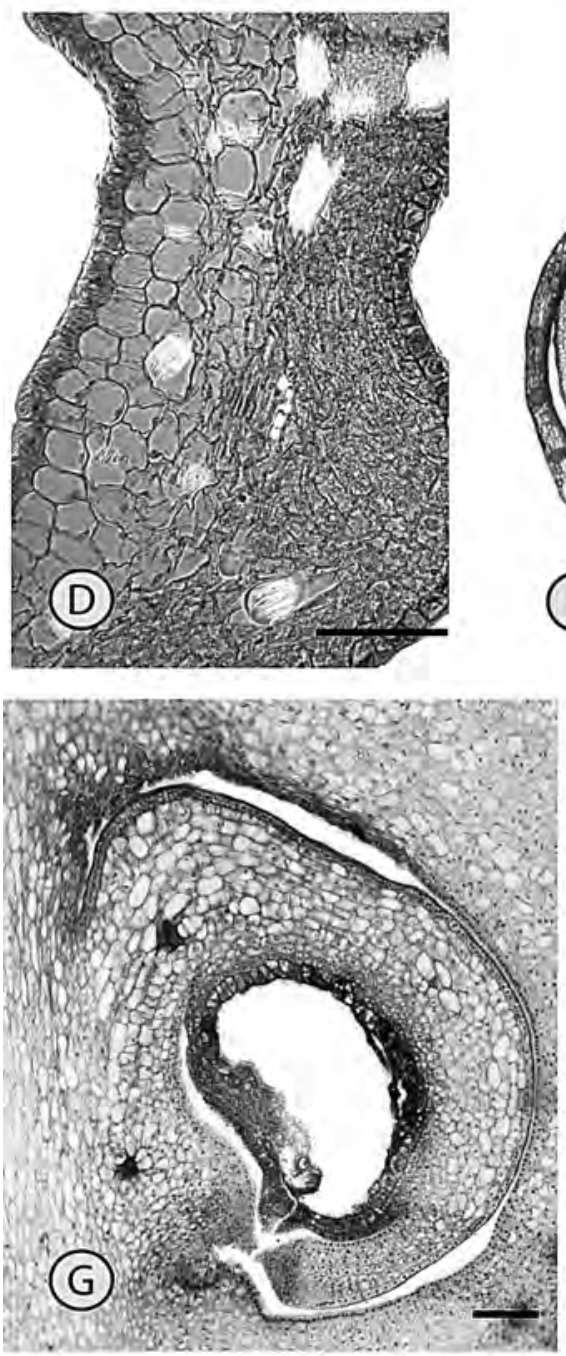
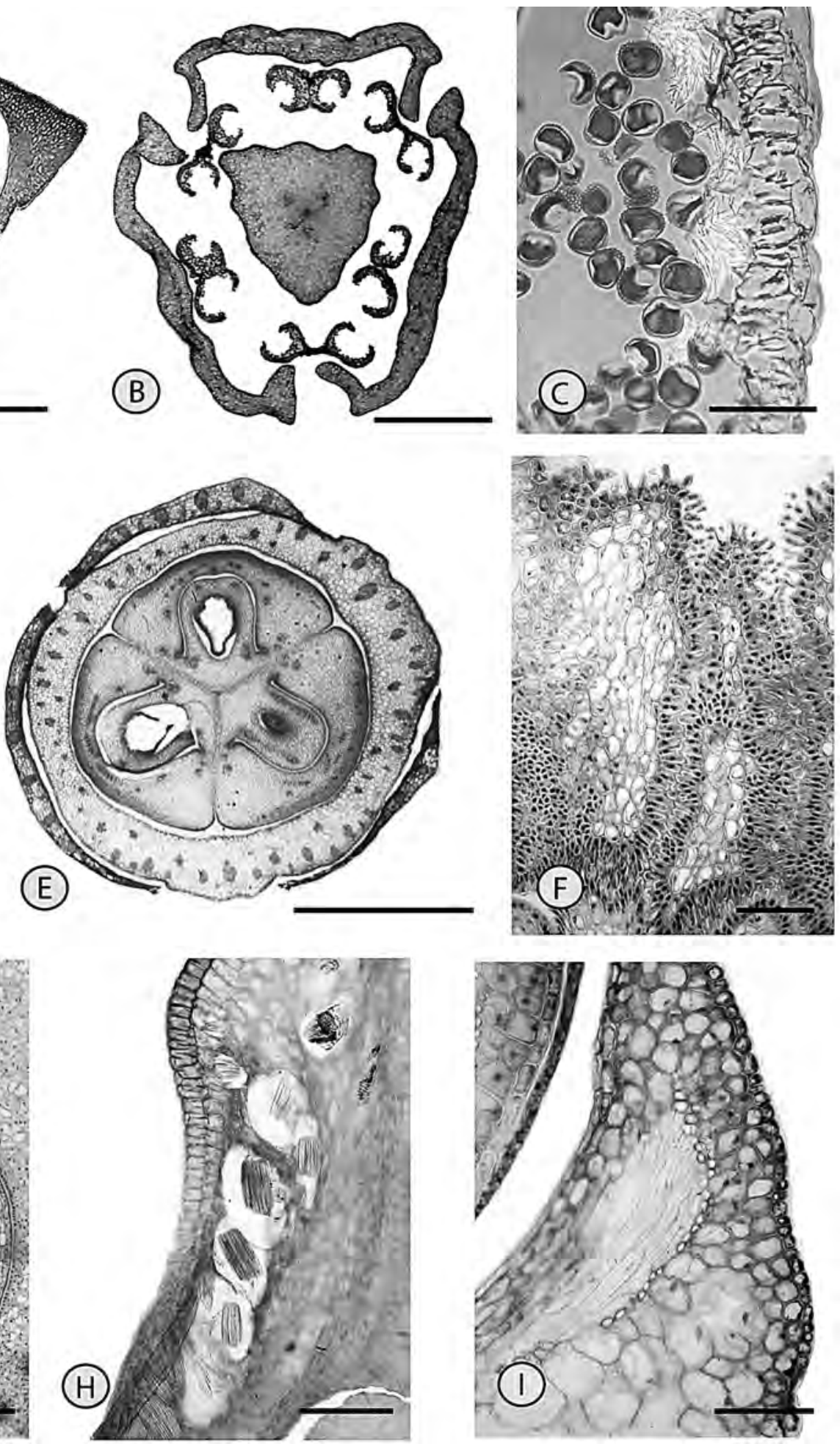

Fig. 4. Floral anatomy of Chamaedorea: A, C. deckeriana, male flower, longitudinal section, scale bar = 1 mm. B, C. brachypoda, male flower, transversal section, scale bar $=1 \mathrm{~mm}$. C, C. fragrans, male flower, longitudinal section of anther with raphide idioblasts, scale bar $=100$ microns. D, C. fragrans, male flower, longitudinal section of petal, histological differences in abaxial and adaxial layers, scale bar $=100$ microns. E, C. elegans, female flower, transversal section, scale bar = $1 \mathrm{~mm}$. F, C. elegans, female flower, longitudinal section of stylar canal, scale bar = 100 microns. G, C. quetzalteca, female flower, longitudinal section of campylotropous ovule, scale bar = 100 microns. H, C. metallica, female flower, longitudinal section of gynoecium with raphide idioblasts, scale bar = 100 microns. I, C. tenella, female flower, longitudinal section of sepal, stegmata along fibres, scale bar $=100$ microns. 


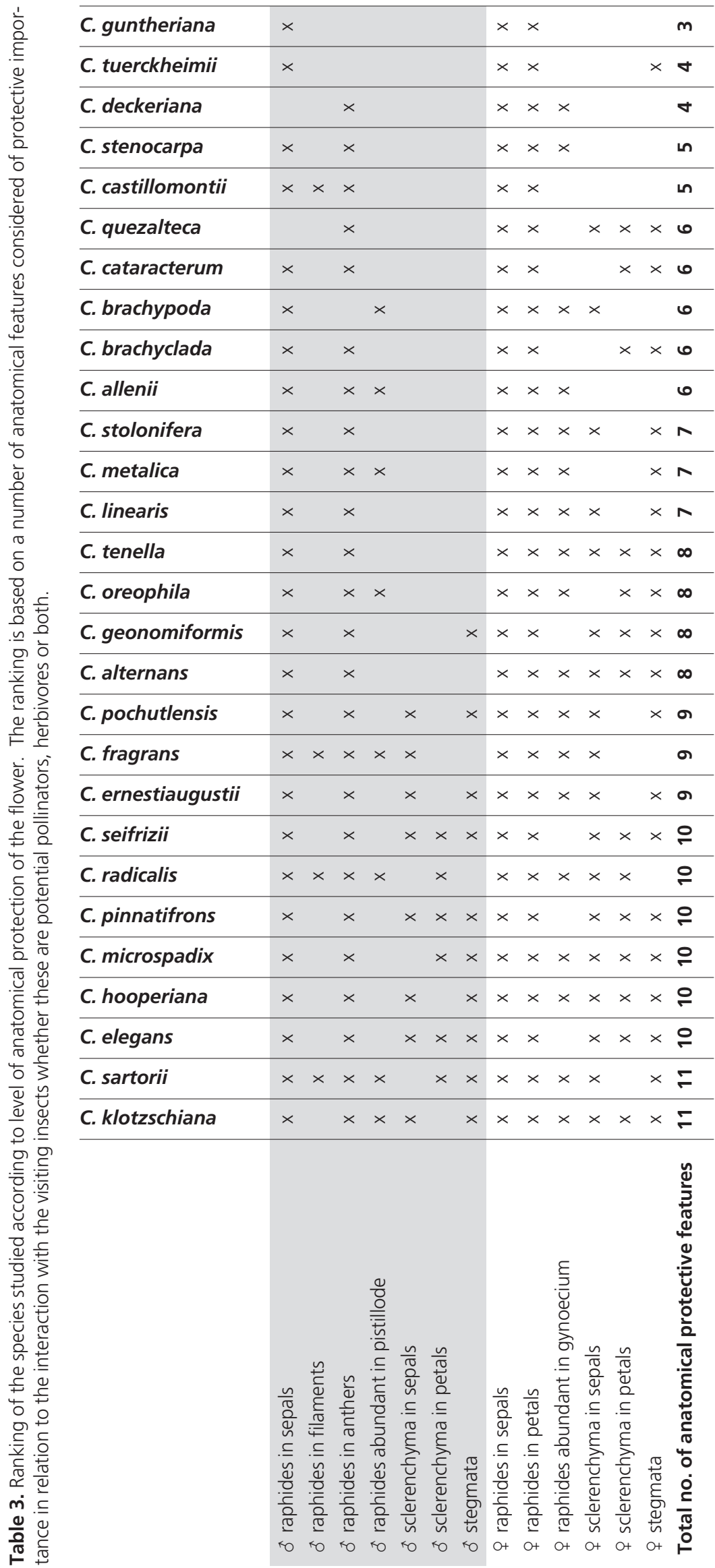


$3.6 \mathrm{~mm}$ and is narrowly to broadly ovoid at anthesis. In a few species such as $C$. elegans the gynoecium appears apocarpous due to incomplete fusion. The three ovaries are uniloculate and uniovulate and more or less even in size and shape at anthesis (Fig. 4 E). The campylotropous ovules are normally attached at the ventral side of the locule (Fig. $4 \mathrm{G}$ ). After anthesis, only one ovule develops to maturity. The three stigmas are sessile and often reflexed at anthesis (Fig. 3 E). They are covered with papillae on the abaxial surface (Figs. 3 H, 4 F). These papillae are usually unicellular, but two-celled papillae were observed in the stigmas of C. fragrans, C. linearis, C. metallica, and C. radicalis. A pollen tube transmitting tract lines the ventral slits of all three carpels, but a proper compitum was not observed in any of the species studied. One lateral and several ventral vascular bundles supply the ovule. The abaxial mesophyll layers in the petals of C. ernesti-augustii, C. fragrans, C. metallica, C. sartorii, C. seifrizii, C. stenocarpa Standl. \& Steyermark, C. stolonifera, and C. tuerckheimii are composed of minute, densely staining cells, which are notably different from those of the adjacent layers. Raphide idioblasts are present in sepals, petals and in the dorsal regions of the ovary, whereas they were rarely observed in the staminodes. Sclerenchyma was found in the sepals and petals of all species. Hatshaped stegmata were observed in the petals of most of the species, but apparently lacking in the sepals. They are typically situated along fibres and vascular bundles (Fig. 4 I). We were unable to detect septal nectaries, but in at least one-third of the species we observed a papillate, epidermal layer with a possibly nectar secreting role that lined the pollen tube transmitting tract.

\section{Discussion}

\section{Inflorescence and the flower cluster structure}

Multiple inflorescences originating from the same leaf axil have been reported in seven genera in the palm subfamilies Ceroxyloideae and Arecoideae. Within the tribe Chamaedoreeae it occurs only in Chamaedorea where it is restricted to male plants, except in $C$. alternans, where multiple inflorescences occur in both male and female plants and occasionally alternates to solitary on the same individual, hence the specific epithet. Although multiple inflorescences in palms develop quite differently, they usually originate from an axillary meristem. Their presence may not only contribute to prolonging the flowering period of the palm (Fisher \& Moore, 1977), but also to increasing the pollen-ovule ratio. Elevated pollen-ovule ratios are often associated with wind pollination (Cruden, 2000).
Flowers in tribe Chamaedoreeae are either solitary or gathered in linear cincinni, also called acervuli (Uhl, 1978). In the genera Gaussia, Hyophorbe, Synechanthus the acervulus is composed of a basal pistillate flower and several distal staminate flowers. In the strictly dioecious Chamaedorea, anatomical evidence has suggested that the solitary flowers have derived from an original acervulate unit by abortion of the distal flowers (Uhl \& Dransfield, 1987). The phylogenetic evidence presented by Thomas \& al. (2006) suggests that multi-flowered condition of the cincinni unique to the subgenera Morenia and Moreniella has developed independently. The novel taxonomic position of Chamaedoreeae in the subfamily Arecoideae, as evidenced by molecular data (Asmussen \& al., 2006), offers new insight into the origin of the triad, another specialized type of cincinnus, which consists of two basal staminate flowers and a distal female flower. Occurrence of triads has previously been considered the only unequivocal synapomorphy for subfamily Arecoideae (Uhl \& Dransfield, 1987). The accuracy of the phylogenetic hypotheses remains too low to reconstruct the shift from the basigynous condition in the acervulus in Chamadoreeae to the acrogynous condition in the triad of the remaining part of the subfamily.

It is generally assumed that unisexual flowers and sexual dimorphism represent derived conditions in palms (Tomlinson, 1990; Bawa, 1980; Bawa \& al., 1985a; Moore \& Uhl, 1982; Richards, 1986). In this context it is noticeable that the staminate flowers of Chamaedorea typically have large pistillodes and that some species within the genus such as $C$. brachypoda have pistillate flowers with prominent staminodes. Studies of the floral ontogeny of selected species of Chamaedorea are in progress and will hopefully provide new insight on the evolutionary origin of these structures. Whether the prominent pistillodes and staminodes have a role as nectar producing organs, feeding tissue, oviposition site etc. is pending further comparative pollination ecological studies.

\section{Possible connections between structural features of the flowers and plant-pollinator interaction}

The small-sized, densely staining cells of the abaxial mesophyll layers of the petals of some species of Chamaedorea have not previously been reported (Fig. $4 \mathrm{D})$. The function of this tissue and whether it plays a role as feeding tissue in the interaction with the pollinating insects remains to be demonstrated. Staining of flowers preserved in $70 \%$ alcohol revealed the presence of neither starches, lipids, nor tannins; however additional studies on fresh material are necessary 
before the presence of these compounds can be ruled out.

Sclerenchyma is composed of two cell types, fibres and sclereids. It is an anatomical specialization, which, in addition to a tissue strengthening function, is considered to play a protective role. Sclerenchyma is omnipresent in the flowers of Chamaedorea, where it often occurs next to or around vascular bundles. Female flowers generally contain more sclerenchyma than male flowers and sepals more sclerenchyma than petals. In the sepals of some species all the cells have thickened walls. Sometimes sclerified tissues can be observed in longitudinal sections of the petals as a continuous layer. In other groups of palms such as cocosoid palms, Nypa fruticans and in some arecoid palms the feature is of diagnostic value (Uhl \& Moore, 1973).

Silica-containing cells (stegmata) have previously been recorded only in the stem and leaves of a few species of Chamaedorea (Tomlinson, 1961; Parthasarathy \& Klotz, 1976). In the flowers of Chamaedorea the stegmata are found near the bundle sheath fibres as in other palms. The presence of silica bodies in both male and female flowers of Chamaedorea most probably serve as protection against the deleterious effects of visiting insects (Uhl \& Moore, 1973).

The tribe Chamaedoreeae is characterized by frequent occurrence of raphide-containing idioblasts in the flowers (Dransfield \& Uhl, 1998). They are present in the anthers of all genera of the tribe abundant in some species of genera Gaussia and Wendlandiella (Henderson \& Rodriguez, 1999). High contents of raphide crystals are known to represent an efficient physical barrier to pollen-eating insects and generally considered a defensive mechanism in palms (Uhl \& Moore, 1973), but their biological significance particularly in pollination and dispersal is unknown (Henderson \& Rodriguez, 1999).

Tissues rich in tanning containing are yet another anatomical feature that is ascribed a protective role. It is widespread in palms and throughout the plant kingdom as well. Its absence from the flowers of Chamaedorea is, against this background, quite remarkable. Tannin-containing cells have only been reported in the basal part of the flowers in C. stolonifera (Uhl \& Moore, 1971).

Based on our findings we have ranked the 28 species of Chamaedorea studied in relation to three protective histological features: sclerified tissue, silica bodies and raphide-containing idioblasts (Table 3 ). The species fall into three groups: 1) male and female flowers both well-protected (11 species), 2) female flowers well-protected and male flowers less protected (12 species) and 3) male and female flowers both moderately protected ( 5 species). Presence of sclerenchyma in both sepals and petals of the male flow- ers is restricted to group 1 whereas stegmata were only observed in the male flowers of species belonging to group 2 and 3.

Based on the rather incomplete sampling size underlying this paper we only found a weak relationship between macro-morphological traits on the one hand and level of anatomical protection on the other. Three species from group 1 and one species from group 2 have orange male flowers. Within group 3 the male flowers are either yellow (1), white (2) or green (3). In group 1 the flowers are generally loosely inserted, whereas half of the species in group 2 have closely aggregated male flowers. In group 3, two species have closely aggregated male flowers. Five of the species included in this study have petals that are connate at the apex. These either belong to group 1 or group 2 (Table 3).

Because of the scattered pollination ecological studies within the genus it is difficult to establish a connection between floral protection and pollinating mechanism. It should be noticed however that within group 1, which is characterized by a high degree of floral protection, both entomophily (1 species), anemophily ( 3 species) and insect-induced wind pollination ( 1 species) prevail. Thus based on a rather incomplete sampling of the species diversity within Chamaedorea it can be concluded that the link between floral anatomical features and pollination mechanism remains unclear.

\section{Floral structure and infrageneric classification}

The infrageneric classification of Hodel (1992a) was based mainly on characters pertaining to petals and architecture of the staminate rachillae. It has since been refuted by phylogenetic analyses, based on low-copy nuclear genes (Thomas \& al., 2006), as well as plastid genes (Cuenca \& Asmussen-Lange, 2007). Only members of the subgenus Eleutheropetalum grouped together either separately (Thomas \& al., 2006), or with C. elegans of the subgenus Collinia (Cuenca \& Asmussen-Lange, 2007). The remainder of Hodel's eight subgenera were paraphyletic or polyphyletic. Interestingly, our analysis of flower structure reveals a suite of both morphological and anatomical characters that are shared by the four members of Eleutheropetalum: Chamaedorea ernestiaugustii, C. metallica, C. sartorii, and C. stolonifera (Table 2). In all species the flowers have orange petals with distinct mesophyll layers of small-sized densely staining cells. The petals of the male flowers are more or less covering the stamens and the pistillode is rich in raphide ideoblasts, especially near the expanded basal part. The female flowers all have valvate petals, well-developed staminodes and raphide idioblasts 
that, although occurring throughout, are concentrated in the peripheral layers of the locular region of the gynoecium.

Reconstruction of morphological characters in palms has revealed a high degree of homoplasy (Baker \& al., 2000; Norup \& al., 2006). This undoubtedly also true for anatomical characters. At the infrageneric level, however, our findings show that flower structure (viz. anatomy and morphology) may be of considerable value for delimiting certain monophyletic groups, alone or in combination. Further insight into the developmental basis for structure of the Chamaedorea flower will undoubtedly lead to a deeper understanding of speciation mechanisms and co-evolutionary relationships within the genus.

\section{Acknowledgements}

We would like to acknowledge laboratory technician Anni Sloth for assistance in the taxonomic laboratory at University of Aarhus, Denmark. The project was conducted as part of the Master's thesis studies of Aino Askgaard at University of Aarhus. The field work was supported by grants from "Ingeniør Svend G. Fiedler og hustrus legat til fremme af botanisk og arkæologisk forskning" and the Faculty of Science, University of Aarhus. Aino Askgaard is grateful to Casper N. Edmonds for companionship in the field work in Costa Rica.

\section{References}

Asmussen, C.B., Dransfield, J., Deickmann, V., Barfod, A.S., Pintaud, J.C. \& Baker, W.J. 2006. A new subfamily classification of the palm family (Arecaceae): evidence from plastid DNA phylogeny. Botanical Journal of the Linnean Society 151: 15-38.

Bacon, C.D. \& Bailey, C.D. 2006. Taxonomy and Conservation: A Case Study from Chamaedorea alternans. Annals of Botany 98: 755-763.

Baker, W.J., Dransfield, J., Hedderson, T.A. 2000. Phylogeny, character evolution, and a new classification of the calamoid palms. Systematic Botany 25: 297-322.

Barry, D. Jr. 1957. Comments on Chamaedorea palms. Principes 1: 91-93.

Bawa, K.S. 1980. Evolution of Dioecy in Flowering Plants. Annual Review of Ecology and Systematics 11: 15-39.

Bawa, K.S., Perry, D.R. \& Beach, J.H. 1985a. Reproductive Biology of Tropical Lowland Rain Forest Trees. I. Sexual Systems and Incompatibility Mechanisms. American Journal of Botany 72: 331-345.

Bawa, K.S., Bullock, S.H., Perry, D.R., Coville, R.E. \& Grayum, M.H. 1985b. Reproductive Biology of Tropical Lowland Rain Forest Trees. II. Pollination Systems. American Journal of Botany 72: 346-356.

Berry, E.J. \& Gorchov, D.L. 2004. Reproductive biology of the dioecious understory palm Chamaedorea radicalis in a Mexican cloud forest: pollination vector, flowering phenology and female fecundity. Journal of Tropical Ecology 20: 369-376.

Croat, T.B. 1978. Flora of Barro Colorado Island. Stanford University Press, Stanford. 169 pp.

Cruden, R.W. 2000. Pollen grains: why so many? Plant Systematics and Evolution 222:143-165.
Cuenca, A. \& Asmussen-Lange, C. 2007. Phylogeny of the Palm Tribe Chamaedoreeae (Arecaceae) Based on Plastid DNA Sequences. Systematic Botany 32: 250-263.

Dransfield, J. \& Uhl, N. 1998. Palmae. In Kubitzki K. Ed. Families and genera of vascular plants, flowering plants: monocotyledons, vol. 4, Springer, Berlin, pp. 306-389.

Dransfield, J., Uhl, N.W., Asmussen, C.B., Baker, W.J., Harley, M.M. \& Lewis, C.E. 2005 A new phylogenetic classification of the palm family, Arecaceae. Kew Bulletin 60: 559-569.

Fisher, J. 1974. Axillary and dichotomous branching in the palm Chamaedorea. American Journal of Botany 61: 1046-1056.

Fisher; J. \& Moore, H.E. Jr. 1977. Multiple inflorescences in palms (Arecaceae): their development and significance. Botanische Jabrbücher für Systematik, 98: 573-611.

Henderson, A. 1986. A review of Pollination Studies in the Palmae. The Botanical Review 52: 221-259.

Henderson, A. 2002. Evolution and ecology of palms. The New York Botanical Garden Press. 259 pp.

Henderson, A. \& Rodriguez, D. 1999. Raphides in palm anthers. Acta Botanica Venezuelica 22: 45-55.

Henderson A., Galeano, G. \& Bernal, R. 1995. Field guide to the palms of the Americas. Princeton University Press, Princeton, New Jersey. pp. 352.

Hodel, D.R. 1992a. Chamaedorea Palms. The species and Their Cultivation. Allen Press, Lawrence. 338 pp.

Hodel, D.R. 1992b. Additions to Chamaedorea palms: new species from Mexico and Guatemala and miscellaneous notes. Principes 36: 188-202.

Hodel, D.R. 1995. Three new species of Chamaedorea from Panama. Principes 39 (1): 14-20.

Hodel, D.R. 1999. Problems interpreting variation in Chamaedorea (Palmae). Memoirs of the New York Botanical Garden 83: 185-189.

Hodel, D.R., Castillo Mont, J.J. \& Zuniga, R. 1995. Two new species of Chamaedorea from Honduras. Principes 39: 183-189.

Listabarth, C. 1992. Insect-induced wind pollination of the palm Chamaedorea pinnatifrons and pollination in the related Wendlandiella sp. Biodiversity and Conservation 1: 39-50.

Moore, H.E. Jr. \& Uhl, N.W. 1982. Major trends of evolution in palms. The Botanical Review 48: 1-69.

Norup, M.V., Dransfield, J., Chase, M.W., Barfod, A.S., Fernando, E.S. \& Baker, W.J. 2006. Homoplasious character combinations and generic delimitation: a case study from the IndoPacific arecoid palms (Arecaceae: Areceae). American Journal of Botany 93: 1065-1080.

Otero-Arnaiz, A. \& Oyama, K. 2001. Reproductive phenology, seed-set and pollination in Chamaedorea alternans, and understorey dioecious palm in a rain forest in Mexico. Journal of Tropical Ecology 17: 745-754.

Parthasarathy, M.V. \& Klotz, L.H. 1976. Palm “wood”. I. Anatomical aspects. Wood Science and Technology 10:215-229.

Ramírez. F. 2002. Manual para el cultivo de XATE. Coordinadora Indígena Campesina Agroforestería Comunitaria Proyecto Sierra de Santa Marta, AC. 40 pp.

Richards, A.J. 1986. Plant Breeding Systems. George Allen \& Unwin, London. pp. 285-330.

Thomas, M.T., Garwood, N.C., Baker, W.J., Henderson, S.A., Russell, S.J., Hodel, D.R. \& Bateman, R.M. 2006. Molecular phylogeny of the palm genus Chamaedorea, based on the lowcopy nuclear genes PRK and RPB2. Molecular Phylogenetics and Evolution 38: 398-415.

Tomlinson, P.B. 1961. Anatomy of the Monocotyledons. II. Palmae. Clarendon Press, Oxford. 453 pp. 
Tomlinson. P.B. 1990. The Structural Biology of Palms. Clarendon Press, Oxford. 477 pp.

Uhl, N.W. 1978. Floral anatomy of the five species of Hyophorbe (Palmae). Gentes Herbarum 11: 246-267

Uhl, N.W. \& Dransfield, J. 1987. Genera Palmarum - A Classification of Palms based on work of Harold E. Moore, Jr. Allen Press, Lawrence. 610 pp.
Uhl, N.W. \& Moore, H.E. 1971. The palm gynoecium. American Journal of Botany 58: 945-992.

Uhl, N.W. \& Moore, H.E. 1973. The protection of pollen and ovules in palms. Principes 17: 111-149.

Associate Editor: S. Talavera Received: 17-III-2008 Accepted: 1-VII-2008 